\title{
Community Involvement in Urban Environmental Management System
}

\author{
Hamidi Ismail ${ }^{1}$, Tuan Pah Rokiah Syed Hussain ${ }^{1}$, Mat Khalid Md Noh ${ }^{1} \&$ Muhammad Subhan ${ }^{2}$ \\ ${ }^{1}$ Development Management Program, School of Government, Universiti Utara Malaysia, Kedah, Malaysia \\ ${ }^{2}$ School of International Studies, Universiti Utara Malaysia, Kedah, Malaysia \\ Correspondence: Muhammad Subhan, School of International Studies, Universiti Utara Malaysia, 06010 UUM \\ Sintok, Kedah, Malaysia. Tel: 60-16-409-4416. E-mail: msubhan@uum.edu.my
}

Received: October 11, 2014 Accepted: December 30, 2014 Online Published: April 30, 2015

doi:10.5539/ass.v11n12p62 URL: http://dx.doi.org/10.5539/ass.v11n12p62

\begin{abstract}
The government of Malaysia has implemented various measures in the environmental management system, such as organizing an urban environmental management program. However, the environmental degradation problem in urban areas in the country is still alarming especially associated with the community engagement in protecting the urban environment. This study attempted to identify the level of community involvement in urban environmental management program in Malaysia based on 320 respondents. The results showed that the planning and enforcement activities by the community in the urban environmental management program were very low. In fact, the study also found that all the respondents in this survey did not execute their monitoring activities due to they assumed that the task should be undertaken by the government. The study concluded that contributing factors to the impairment of urban ecosystems in the study area is due to the vulnerability level of community involvement. Therefore, a better urban environmental management system is important to ensure higher community involvement in the urban environmental management program in strong collaboration with other concerned parties, especially the relevant government departments and the local authority.
\end{abstract}

Keywords: Community involvement, environmental studies, urban planning, community enforcement, community monitoring, urban pollution, Malaysia

\section{Introduction}

Community involvement in urban environmental management system covers various activities such as planning, enforcement and monitoring in collaboration with government, private and non-governmental organizations (NGOs). Community involvement in environmental management within the area of Kajang Municipal Council (MPKj), Selangor, Malaysia involving air quality care programs and urban river water is very important to determine whether the management system carried out by the current government really works. The government has implemented various measures in the environmental management system in an urban area such as organizing environmental program, but environmental degradation problems still occur and this is associated with the vulnerability of society to engage in the protection of the environment of the municipality. The obvious question is to what extent the level of community involvement in urban environmental management program should be.

Environmental impairment and in particular in the urban ecosystem is evident currently in the MPKj area as shown by research of the River Zone Conurbation of Cheras-Kajang-Bangi in the period 1974-2001 (Aiyub \& Hasim, 2005). The study found that the Langat ecosystem started having problem of drastic changes since the 1980 s that led to the contamination of drinking water quality and impact on ecosystem health. A study conducted by the Department of Environment also found a total of 150 industrial units operating around the Langat Basin and a total of 56 industries have violated standards of environmental pollution that can adversely affect the main source of water supply for the population in Klang Valley (Department of Environment [DOE], 2000). In fact, for Langat River it is at the average level with recorded contamination of Water Quality Index (WQI) up to 74 (DOE, 2007). Similarly, the DOE report also indicated that Langat River has remained at a moderate level contamination with WQI reading of 74 (DOE, 2008). This certainly shows that the contamination occurred in the MPKj reflects the current environmental management system including community involvement is still questionable. 
Ecosystem deterioration in MPKj today is a crucial issue due to the increasingly robust development. Human involvement in the development based on daily activities, eventually contributed to the deterioration of the ecosystem such as air and water quality of the river. The local authority today face challenges of rapid urban development which is filled with a variety of human activities such as manufacturing, business and domestic. The urban ecosystem declines related to occurring disorder is the result of the interaction of human activities such as commerce, industry and domestic sector of the population in urban areas with the physical environment of a city (Carvalho \& Fidelis, 2009). Man is an agent of change to the physical environment in line with the development of urban civilization in the context of an urban setting. In fact, in the context of development, people who use the input of energy, materials and technology to carry out daily activities in a city could create urban ecosystem deterioration intentionally or unintentionally (Jahi, 1996; Hussain \& Ismail, 2013). Even everyday activities by human development in a town have created too much problems to the ecosystem despite the positive impact of the development (Hassan, Awang, \& Jaafar, 2006; Pini, River, \& McKenzie, 2007; Subhan, Ghani, \& Joarder, 2014). The beneficial effects left by urban development such as an opportunity increase to quality of life, economic growth and physical development of urban city are certainly needed by society. While the adverse effects left by the development of urban ecosystems involved such as air and water pollution that would ultimately affect health, comfort and safety of city population.

Hence, human interaction within an urban space should be improved with more effective management system (Deason, 2009). Consideration has to be based on careful planning involving socio-economic factors, technology and ecology because of the inter-relatedness of these factors in determining urban social harmony (Fisch, 1982). Also, problems of urban ecosystems are due to the function of the city itself which normally use limitless of natural resources just to meet the needs of residents (Perman \& Anand, 2000; Yang, Su, \& Xu, 2006). Whatever the cause of deterioration of urban ecosystems, human behavior is actually the main identified cause as shown by low involvement in managing the urban environment (Rice, 2010). So, active community involvement is essential for the success of a management program prepared by the authorities on the environment.

Previous research has touched many issues related to the role of a private individual or society only in the care of the environment (Harrigan \& Vogel, 2003; Petukhov, 2006). However, a study in the Hindu Kush, Himalaya found that urban ecosystem deterioration is caused by a failed management system and needs a high community involvement by all parties (Yang, Su, \& Xu, 2006; Osti, 2004). In contrast, other researchers found that issues relating to the implementation of policy are the problem (Kyvelou \& Filho, 2006; Lockwood, Davidson, Curtis, Stratford, \& Griffith, 2009; Enserink \& Koppenjan, 2007; Morrison, 2007). A study by Measham and Barnett (2008) also found that motivational issues are involved in the volunteerism for environmental management and motivation is related to volunteerism attitude and should exist and enhanced to reduce the impairment of urban ecosystem. Furthermore, studies by Larsen (2011) are characteristically institutional and he found that the government or city authorities failed to carry out the policy due to problems of ambiguity in the existing policy. However, his study did not focus on urban environmental management system alone, but more to environmental management in the context of Malaysia.

\section{Study Area and Research Methods}

MPKj is located in the western part of Pahang, southeast of Petaling District, northeast of Sepang and north of Negeri Sembilan with an area of approximately 226.8 hectares. Administrative area of the whole MPKj is 787.61 square kilometers (78 761 hectares) consisting of six mukims of Kajang, Semenyih, Hulu Semenyih, Beranang, Hulu Langat and Cheras. The MPKj total population in 1998 was 157500 people and in 1999 the population increased to 232250 people and in 2007 the population reached 653793 people based on an annual growth rate of 4.2 per cent. The increase in population is driven by factors such as the effect of spill-over from the development of Kuala Lumpur and Klang Valley. The built-up area of the housing sector accounts for 7854.57 hectares of the total municipal area of 78761 hectares in 2009. Statistics in 2007 showed that the main focus of the population in Kajang urban areas is Mukim Kajang, Cheras, Semenyih and Hulu Langat.

The sampling for this survey in MPKj area was performed using cluster sampling technique. As the population of the study area is huge and in various mukims as well as types of homes, so it's rather impossible for researchers to do random sampling of the population and to collect too many samples. Therefore, for the purposes of this study, cluster sampling was chosen because it can reduce the number of samples which is too large in such a wide area. For MPKj area, the total number of dwelling units including slum dwelling is 198265 units of the residence population of 653793 people. Sample selection process was started from the amount of residential dwelling types divided according to the cluster of bungalows, terraced, flat, Malay villages, Chinese villages, slum and shophouses which are important residential community. In fact, the distribution of clusters on a number of residential types is to ensure or assume that participants could represent the diversity level, class or 
group of people in a particular location. At this stage, an important process done is to ensure that residential areas or residential dwelling are in accordance with the type prescribed in the study. After that, field visits were carried out to determine the study residential area and to calculate the number of residential units for the purpose of determining the sample size. During the field visits conducted by the researchers, only residential areas meeting the study specifications are selected as the basis of sampling. Although there are a number of residential areas, only one area was selected to represent that particular dwelling type assuming that respondent characteristics are homogenous. Therefore, this study has considered its study area based on the sampling distribution of the residential clusters in MPKj area as shown in Table 1.

Table 1. Total sample size in the study area

\begin{tabular}{cllc}
\hline No. & Types of Dwellings & Name of Residential Area & Total Sample \\
\hline 1. & Bungalows & Phase 2, Bandar Baru Bangi & 30 \\
2. & Terraced & Section 3, Bandar Baru Bangi & 120 \\
3. & Flat & Phase 4, Bandar Baru Bangi & 50 \\
4. & Shophouses & Jalan Reko & 30 \\
5. & Malay Villages & Sungai Ramal Dalam & 30 \\
6. & Chinese Villages & Kampung Baru Semenyih & 30 \\
7. & Slum & Balakong & Total: \\
\end{tabular}

Once researchers have identified the study areas and types of dwelling in the sample survey, proportionate sampling method was used to determine the size of the sample. This method is done by specifying the percentage of samples that must be taken which are not too small and not too large in size. Table 1 specifies the percentage of the sample and the size used in the study area. Then, the next process is to determine the number of samples using stratified sampling method. Further, the process of determining the residential units as a sample of respondents is by using the method of total housing units in residential areas specified divided by number of samples determined by using proportionate sampling. By this method, the researchers will acquire residential unit in interval for the sample of respondents. However, the residential units involved with this method of sampling will be used as sample with the head of household is the respondents. If the head of household consisting of head of the family or the husband is not available, the wife is instead of acting as a respondent. Similarly, if the units involved with sampling is unoccupied or not at home, then the next house is to be served as sampling unit respondent sampling unit.

This study set the minimum limit of a total of 30 sample respondents based on the opinion of most other researchers (Carver \& Nash, 2005; Sekaran, 2003). The sample size of not less than 30 is very important actually to keep the quality of the data as the number of samples is generally capable of being analyzed using statistical tests. In fact, the whole sample is considered appropriate and adequate because it was not less than 10 percent (Dixon \& Leach, 1978). The use the cluster technique is not a new thing as it was done by other researchers in various fields and aspects of the study.

Having clearly defined sampling process, the study is done using a set of questionnaire forms tailored to suit the type of analysis. All questions are designed based on the form of Likert scale from 1 to 5 (very low to very high). Analysis technique used is the statistical analysis of the correlation or Spearman correlation involving two variables, the independent and dependent variables with both characterized by an interval data or ratio (Carver \& Nash, 2005; Md Nor, 2009). In this case, the correlation coefficient is an important indicator that reflects the strength of the relationship between the variables. The value of the correlation coefficient ( $\mathrm{P}$ value) approaching +1.0 reflect a strong positive relationship between the two variables of the study. An increase in one variable affects the increase of the other variable. While if the coefficient is approaching -1.0 it indicates a stronger negative correlation (inverse) between the two variables.

For the purpose of predictive analysis, the studies use multivariate regression techniques. Basically, this technique uses a set of variables consisting of one dependent variable of either interval or ordinal data with two or more independent variables (predictor variables) also of the data interval, ordinal or categorical. The purpose of this analysis is to enable us to see the influence of the relationship between the independent variable on the dependent variables (Md Nor, 2009). Interpretation of the results of this analysis usually refers to the value of $\mathrm{R}^{2}$ with the value getting closer to one reflects a stronger relationship between the dependent and independent variables. For example, if the analysis shows the relationship between the variables of $\mathrm{R}^{2}=0.56$, then the relationship is at 56 percent. The significant degree for this analysis also bound to not more than $0.05(\mathrm{P}=0.05)$. 
However, the conditions for this analysis is the distribution of data is necessarily normal or almost normal condition by testing the $\mathrm{K}-\mathrm{S}$ or $\mathrm{S}-\mathrm{W}$ to ensure that there is not too much residual data.

Before the actual research is conducted, initial field study was conducted on 13 and 14 of May 2011 in the MPKj area by taking a sample of more than 30 respondents amounting to 50 samples to ensure that the pilot study and the survey sets are more reliable. Respondents consisted of five major types of residential bungalows, terraced, flat, house Malay and Chinese house with every type of residential is distributed with 10 samples. Preliminary studies are done to determine the reliability of the set of survey and test results found the Cronbach Alpha of 0.729 which demonstrates that the set of questions posed moderately high proportion and can be used for research (Md Nor, 2009). While in the distribution of data normality, the pilot study found the value of KS to be 0.745. This shows that the distribution of the data is normally distributed at medium range and inferential statistical tests such as those used in this study, namely Spearman Rho Correlation and Multivariate Regression can be accomplished.

\section{Results and Discussion}

\subsection{Level of Community Involvement in Program Planning}

To examine the level of community involvement in the context of urban environmental management planning, discussion is divided into a number of things such as the followings:

\subsubsection{Level of Community Involvement in the Planning}

Studies show that the level of community involvement in environmental management planning is still low thus leading to the existence of urban ecosystem deterioration issues. The proof, the study results show the environmental management program planning MPKj area is significant at a level of around 0.000 that is to say that community-level management does exist based on correlation analysis but, the relationship is very weak because regression analysis showed only 10 per cent of the strength of relationship $\left(\mathrm{R}^{2} 0.10\right)$. Thus, the pattern of involvement of the community to manage environmental planning in MPKj is showing weakness that led to the existence problem of deteriorating urban ecosystem.

\subsubsection{Individual Program Planning in Environmental Management}

The individual level of community involvement in urban environmental management planning is still low. The proof, correlation analysis in environmental management program planning within MPKj area is significant in particular effort in terms of "the use of unleaded fuel vehicles, plant trees, do not throw garbage into drains and drain cleaning for the purpose of avoiding mosquito or diseases". They are not going to do difficult activities such as "car-pooling, using public transportation and refining kitchen waste using grease traps". However, regression analysis also showed that there is a very weak relationships between 1 and 8 per cent based on the reading of $\mathrm{R}^{2} .01-.08$. The problem of low level of involvement in the planning of environmental management by the individual for the MPKj could create impairment of the urban ecosystems. Whereas, in order to create a good urban ecosystem, high involvement of all parties are indispensable to any plan being implemented by the government to achieve success.

\subsection{Community as Representative in the Policy-Making for Environment Management}

In the context of the community as representative in decision-making about environmental management policy planning also seems less clear, which is still weak and this led to induced impairment of urban ecosystems. In general, the study found that respondents with high incomes in MPKj area and respondents with higher number of family members are more likely to be involved in the planning of environmental management at the policy level based on correlation analysis. However, urban environmental management planning among respondents as representatives in related policy-making is insignificant based on regression analysis. This shows that respondents' duties as representatives in policy planning are rather unclear or their level of involvement is still low based on the evidence of the correlation analysis where only total income and number of family members as policy planners are found to be significant.

\subsection{Level of Community Involvement in the Enforcement Program}

This section discusses the study results involving the participation of society in the enforcement activity of an environmental management system for the city of MPKj. Enforcement program in the urban environmental management is based on participation or actions taken by the community, private sectors and NGO in collaboration with the government to manage the environmental aspects of municipal waste, urban air and water quality of the river. This activity is fundamental in ensuring the legal enforcement system as a whole in managing the urban environment (Ismail, 2014; Hussain, Md Noor, \& Ismail, 2014). 


\subsubsection{Involvement in Environmental Management Program Organized by the Government}

In the context of community involvement, participation in urban environmental management program is very important because the active participation of this group could change the status of the environment of an urban area. In fact, the community has the power or effort that can determine the success of an environmental management system implemented by the city government. If society does not give a good involvement in the enforcement of the environmental management system of the city, then the ecosystem deterioration will occur on an on-going basis. Therefore, it is important that the awareness of the community to participate in any program be addressed by local authorities. However, the study found that community involvement in environmental management program hosted by the government does not exist based on the regression analysis of insignificant level at 0.05 . However, there is a significant relationship based on the analysis of correlation between the community and participation in related governmental programs based on respondents' age and income, but the relationship is too weak as regression analysis showed no significant relationship of respondents with the program hosted by the government. These circumstances may be caused by the fact that there are only two variables of age and income that are significant. Weaknesses in the participation from the aspects of age and income are evidenced by regression analysis with $\mathrm{R}^{2}$ values of around 6.8 to 7.0 percent.

\subsubsection{Community Action in the Environmental Management Program Organized by the Government}

In terms of community action in the environmental management program organized by the government is also very important concern as the government sponsored program will be a success if people are equally actively involved. In terms of community action in the environmental management program organized by the government also show there are problems associated with the low level of involvement. The correlation analysis showed that respondents MPKj areas do not take any action in the care of air and water quality. This situation is further strengthened through the regression analysis which showed that there is no significant relationship between respondents with caring for of air and water quality. Therefore, it can be concluded that the level of community involvement through their actions in the program organized by the government is low. This situation causes problems of maintenance of environmental quality such as air and water failed to be managed well by the government. Whereas, organizing a program involving the care of the environment is the most fundamental of an environmental management system involving the community with government departments. However, the community does not take action to support the programs organized by the government. This condition can cause environmental degradation of a city like MPKj area.

\subsubsection{Community Action in the Environmental Management Program Organized by the Private Sector}

Similarly, the community action program organized by the private sector show that there is the same problem as the program organized by government departments. Although government departments should be the most important agent in the success of environmental enforcement system to manage the city, but no doubt that the private sector also needs to play a role in supporting the efforts made by the government. For the purpose of caring for the environment and to show a sense of responsibility of the private sector, the environmental program implemented by these parties need to be supported by the community. The problem that occurs is a community failed to provide good cooperation to support the efforts made by the private sector. The study found that the respondents' action in the environmental management program organized by the private sector, there were only factors of number of family members and income that have significant relationship with the air and water care at the level of 0.000 for the MPKj. Thus, it can be concluded that the level of involvement of the respondent or society through support of private sector organizing program for the care of air and water quality is still low for the area. This situation actually led to a deterioration of the problem of the urban ecosystem if the effort by the private sector fails to inspire the community to take serious action or even not supported by the community at all.

\subsubsection{Community Action in Managing the Environment Based on Individual Initiative}

Community action to manage the urban environment, such as air and water quality based on individual initiative is also very important to be addressed at the micro level. This is because their movement towards creating a clean and healthy environment implies that the urban communities have high levels of awareness and concern about environmental quality care. If they fail to take action for the benefit of the environment, such as managing the self, then the degradation of the environment will occur, and thus defeats the enforcement system by the government. However, the study found that individual based initiatives in environmental management showed a significant correlation with age and number of family members at the level of 0.000 . Although there is a relationship, but the regression analysis shows a weak relationship with around 5 to 15.4 percent of value $\mathrm{R}^{2}$, but significant at the 0.05 level. Therefore, the whole aspect of community involvement in the enforcement of the environmental management system in MPKj urban areas is relatively low or weak based on the previous 
discussions. The weaknesses involve the aspects of community action in the environmental management program organized by the government, private and individual initiative. Weak involvement of the respondents who are actually in the context of enforcement of environmental management system carried out by the government is able to thwart environmental policy at urban or country level. At the same time it also illustrates an urban society as vulnerable groups in the context of environmental management. This prompted an impairment of urban ecosystem and affects the quality of the environment such as air and water.

\subsection{Level of Community Involvement in Monitoring Program}

In addition, the level of community involvement is considered important in the framework of an urban environmental management system monitoring because without such community involvement in this matter, certainly environmental degradation problems still continues. However, the study found that monitoring problems still occur. This is due to the facts that all the respondents in the MPKj do not do their monitoring activity as they presume that the task should be undertaken by the government. This situation illustrates that the environmental management system of the city from the aspect of monitoring by the community is weak. This vulnerability actually encourages the ease to pollute the environment. If the whole the community can give full cooperation in the monitoring of the environment together with the government, the problem of environmental pollution is rare. Therefore, it can be said that the degradation of urban air and river water is closely associated with the failure of the society at large to monitor the urban environmental management system.

\section{Conclusions}

Therefore, based on the study it can be concluded that the level of community involvement in the MPKj area through urban environmental management program today, particularly to overcome the problem of deteriorating air quality aspects of urban ecosystems and river water is still low. Weakness of community involvement in the program as discussed above can be seen from the planning, monitoring and enforcement efforts in managing their environmental or urban residential areas. Regression analysis tested still showed very weak level of their involvement, although in many cases the correlation test conducted is still at significant levels. This indicates that urban ecosystem decline is due to the weakness of community involvement in urban environmental management program. This situation actually requires an environmental management system to ensure better community involvement in environmental management in conjunction with other parties, especially the relevant government departments such as the Local Authority. In fact, in line with previous studies it is also found that community involvement with other parties such as government, private sector and NGOs is essential to ensure that urban environmental management system can achieve success.

\section{References}

Aiyub, K., \& Hasim, N. M. (2005, September 5-6). Peningkatan litupan tepubina bandar di Zon Persisir Sungai Konurbasi Cheras-Kajang-Bangi 1974-2001: Implikasinya terhadap kesihatan ekosistem Langat. Paper Presented at Persidangan Kebangsaan Kedua PPSPP. PPSPP, Universiti Kebangsaan Malaysia.

Carvalho, D. S., \& Fidelis, T. (2009). Confronting environmental perceptions of local populations and local authorities. Management of Environmental Quality: An International Journal, 20(5), 538-550. http://dx.doi.org/10.1108/14777830910981212

Carver, R. H., \& Nash, J. G. (2005). Doing data analysis with SPSS Version 12. Thomson Books/Cole.

Deason, J. P. (2009). Restoring contaminated urban rivers using an intergovernmental, public-private approach. Management of Environmental Quality: An International Journal, 20(6), 649-657. http://dx.doi.org/ $10.1108 / 14777830910990762$

Dixon, C. J., \& Leach, B. (1978). Questionnaires and interviews in geographical research. Institute of British Geographers.

DOE. (2000). Environmental Quality Report 2000. Ministry of Science, Technology and Environment.

DOE. (2007). Environmental Quality Report 2007. Ministry of Science, Technology and Environment.

DOE. (2008). Environmental Quality Report 2008. Ministry of Science, Technology and Environment.

Enserink, B., \& Koppenjan, J. (2007). Public Participation in China: Sustainable urbanization and governance. Management of Environmental Quality: An International Journal, 8(4), 459-474. http://dx.doi.org/10.1108/ 14777830710753848

Fisch, O. (1982). Technological transfer of regional environmental models (Vol. 8). In M. Albegove, A. E. Anderson, \& F. Snickars (Eds.), Regional development modeling: Theory and practice (pp. 127-142). 
Amsterdam: North-Holland Publishing Company.

Harrigan, J. J., \& Vogel, R. K. (2003). Political Change in the Metropolis (7th ed.). Addison-Wesley Educational Publishers Inc.

Hassan, M. N., Awang, M., \& Jaafar, A. B. (2006). Challenges of global environmental issues on ecosystem management in Malaysia. Aquatic Ecosystem Health \& Management, 9(2), 269-283.

Hussain, T. P. R. S., \& Ismail, H. (2013). Flood Frequency Analysis of Kelantan River Basin, Malaysia. World Applied Science Journal, 28(12), 1989-1995. http://dx.doi.org/10.5829/idosi.wasj.2013.28.12.1559.

Hussain, T. P. R. S., Md Nor, A. R., \& Ismail, H. (2014). The level of satisfaction towards flood management system in Kelantan, Malaysia. Pertanika J. Soc. Sci. \& Hum., 22(1), 257-269.

Ismail, H. (2014). Sistem pengurusan alam sekitar dalam Majlis Perbandaran Kajang Dan Majlis Perbandaran Seremban (Unpublished PhD Thesis). Universiti Kebangsaan Malaysia, Bangi.

Jahi, J. M. (1996). Impak pembangunan terhadap alam sekitar. Universiti Kebangsaan Malaysia Press.

Kyvelou, S., \& Filho, W. L. (2006). Sustainable Management and Urban Space Quality in the Mediterranean: Challenges and perspective. Management of Environmental Quality: An International Journal, 17(5), 611-624. http://dx.doi.org/10.1108/14777830610684576

Larsen, P. B. (2011). Municipal environmental governance in the Peruvian Amazon: A case study in local matters if (in) significance. Management of Environmental Quality: An International Journal, 22(3), 374-385. http://dx.doi.org/10.1108/14777831111122932

Lockwood, M., Davidson, J., Curtis, A., Stratford, E., \& Griffith, R. (2009). Multi-level environmental governance: Lessons from Australian natural resource management. Australian Geographer, 40(2), 169-186. http://dx.doi.org/10.1080/00049180902964926

Md Nor, A. R. (2009). Statistical methods in research. Prentice Hall.

Measham, T. G., \& Barnett, G. B. (2008). Environmental volunteering: motivations, modes and outcomes. Australian Geographer, 39(4), 537-552. http://dx.doi.org/10.1080/00049180802419237

Morrison, T. H. (2007). Multiscalar governance and regional environmental management in Australia. Space and Polity, 11(3), 227-241. http://dx.doi.org/10.1080/13562570701811551

Osti, R. (2004). Forms of community participation and agencies' role for the implementation of water induced disaster management: Protecting and enhancing the poor. Management of Environmental Quality: An International Journal, 3(1), 6-12. http://dx.doi.org/10.1108/09653560410521643

Perman, R., \& Anand, P. B. (2000). Development and the environment: an introduction. Journal of Economic Studies, 27(1), 7-18. http://dx.doi.org/10.1108/EUM0000000005308

Petukhov, V. (2006). Political participation and civic self-organization in Russia. Russian Social Science Review, 47(6), 4-22. http://dx.doi.org/10.1080/10611428.2006.11065232

Pini, B., River, S. W., \& McKenzie, F. M. (2007). Factors, inhibiting local government engagement in environmental sustainability: Case studies from rural Australia. Australian Geographer, 38(2), 161-175. http://dx.doi.org/10.1080/00049180701399985

Rice, J. L. (2010). Climate, carbon and territory: Greenhouse gas mitigation in Seattle, Washington. Annals of the Association of American Geographers, 100(4), 929-937.

Sekaran, U. (2003). Research methods for business: A skill building approach (4th ed.). John Wiley \& Sons.

Subhan, M., Ghani, A. B., \& Joarder, M. H. (2014). Urban Community Willingness to Pay for Improved Solid Waste Management in Malaysian Municipality: A Choice Modeling Approach. Asian Social Science, 10(18),122-136. http://dx.doi.org/10.5539/ass.v10n18p122

Yang, Z. F., Su, M. R., \& Xu, L. Y. (2006). A case study of urban environment-economic management in Xiamen, China. Aquatic Ecosystem Health \& Management, 9(1), 85-91.

\section{Copyrights}

Copyright for this article is retained by the author(s), with first publication rights granted to the journal.

This is an open-access article distributed under the terms and conditions of the Creative Commons Attribution license (http://creativecommons.org/licenses/by/3.0/). 